\title{
SEASONAL DIFFERENCES IN THE DECOMPOSITION OF Typha angustifolia LEAVES IN A MEDITERRANEAN RIVER
}

\author{
N. Jaques \& P. Pinto \\ Dep. Biologia, Universidade de Évora, P-7001 Évora, CODEX Portugal.
}

Keywords: Decomposition, Mediterranean river, Typha angustifolia.

\section{SUMMARY}

This study evaluated seasonal differences (spring and summer) in the processing of Typha angustifolia leaves in a Mediterranean river. The experiment extended over 120 days, corresponding to six sampling periods for each experiment. Leaves $(5 \mathrm{~g})$ were placed in $0.5 \mathrm{~cm}$ mesh-size bags. After recovering the sample, macroinvertebrates inside the leaf bags were retrieved and the leaves preserved by freezing. The dry mass, nutrients $(\mathrm{N}$ and $\mathrm{P}$ ), cellulose, hemicellulose and lignin contents were measured. The litter breakdown proceeded at an exponential rate, higher in spring $\left(\mathrm{k}=0.0098 \mathrm{~d}^{-1}\right)$ than in summer $\left(\mathrm{k}=0.0031 \mathrm{~d}^{-1}\right)$. This coincided with the highest current speed and dissolved oxygen concentration. The decay patterns of lignin, cellulose and hemicellulose suggest the existence of two phases dunng the aquatic decomposition, influenced by the previous terrestrial conditioning.

\section{INTRODUCTION}

In Mediterranean regions, leaf fall is not restncted to a small period of the year as in temperate regions, due to more uniform climatic conditions and to the dominant flora. Thus, dynamics of coarse particulate organic material in Mediterranean rivers are different from those in temperate rivers of higher latitudes, where leaf decomposition is weli documented (GRAÇA, 1993). In addition, the temporary characteristics of many of these rivers allow macrophyte growth on the river bed when the water flow is reduced or absent. Some of these macrophytes, such as Typha angustifolia, remain in a standing dead phase on the river bed during long periods, and are subjected to different actions (wind, water flow) that initiate their decomposition (BARLOCHER \& BIDDISCONBE, 1996) and their export.

Typha angustifolia is one of the most abundant macrophytes of the river Degebe, as weli as of other rivers from the Southeast of Portugal. Large and dense mats of this macrophyte usually extend for several metres into the river bed, and a large amount of decomposing leaf fragments occurs all along the river, even some distance from Typha beds.

The high densities of Typha angustifolia in Mediterranean rivers strongly influence the dynamic of organic matter; however, the decomposition process of this species is itself poorly

Limnetica, 13 (2): 19-23 (1997)

J. Pozo \& A. Elosegi (eds),

Proceedings of the European Meeting on Litter Breakdown in Rivers and Streams

c) Asociación Española de Limnología, Madrid, Spain. documented (MASON \& BRYANT, 1975; BARLOCHER \& BIDDISCONBE, 1996). The objective of this study was to compare the aquatic decomposition of Typha angustifolia under different ecological conditions during spring-summer and summer-autumn.

\section{MATERIAL AND METHODS}

Experiments were conducted in the headwaters of Degebe river, a first order stream from Guadiana Basin, located on a plain in Southeast Portugal. The experiments were conducted in a permanent pool which was clearly influenced by the temporary characteristics of this stream. Water flowed during winter and spring, while in summer and early autumn the pool was stagnant.

Sections of Typha angustifolia leaves, $10 \mathrm{~cm}$ long, $30 \mathrm{~cm}$ from the top, were cut from senescent plants, assembled in leaf packs and placed inside $5 \mathrm{~mm}$ mesh plastic bags. The experiments were conducted during two periods: spring to summer (26 March to 28 August) and summer to early autumn (15 June to 27 October). For each period 18 pairs of bags containing $5 \mathrm{~g}$ of leaves were distnbuted randomly in an homogeneous zone. Three pairs of bags were retrieved at predetermined intervals $(1,7,14,28,63$ and 157 days during the first experiment; 1,7 , 
$14,43,76$ and 134 days during the second experiment), kept in plastic containerc with stream water, and returned to the laboratory. On each sampling occasion, we measured dicsolved oxygen (WTW Oxi 196), pH (WTW pH 196T) and conductivity (WTW CF 196).A water sample was returned to the laboratory to measure the nutrients (APHA. 1992).

At the laboratory, the macroinvertebrates were removed and preserved in a $5 \%$ formalin solution to be identified. The leaf sections were dried at $60{ }^{\circ} \mathrm{C}$ over three dayc for dry mass. and ground to evaluate the percentage of cellulose, hemicelluloce and lignin by the gravimetric method of GOERING \& VANSOEST (1970). Nitrogen was determined by the Berthelot method and phosphorus by the molibdate blue method using ascorbic acid, after digection with sulphuric acid. Methods followed APHA (1992). The mean dry mas: of the fresh leaf cections used during the experimente wac estimated from a sample of twenty leaves.

The decay rate was estimated by an exponential model (WIEDER \& LANG, 1982; CHAUVET, 1987; NEWMAN \& PERRY, 1989):

$$
m_{r}=m_{0} e^{-k t}
$$

where $m_{t}$ is the mass remaining at time $t, m_{\theta}$ is the initial mass and $k$ is the decay coefficient.

\section{RESULTS}

The physico-chemical parameters of water are presented in table 1. Dissolved oxygen content was clearly higher during the first experiment, and temperature slightly higher in the second. Conductivity tended to be higher in the second experiment. No clear differencec appeared in phosphorus and nitrogen. There was no water current during the second experiment.

The decay coefficients (table 2) were higher for the first period, denoting a higher decomposition rate of Typha angusti- folia leavec during the spring than during summer; however. the decay pattern was quite similar for the first samples, and differencec are clear only in the lact sample (fig. 1).

Three different patterns of decay were observed for the principal compoundc of the leaves (fig. 2). Cellulose disappeared slowly, in contrast to hemicellulose, that showed the highect decay rate. Lignin increased in the early samplec for both periodc. In spring it was impossible to evaluate the compounds of the leaves in the last sample, due to the insufficient masc remaining.

The nutrient content of leaves (fig. 3) tended to increase. For

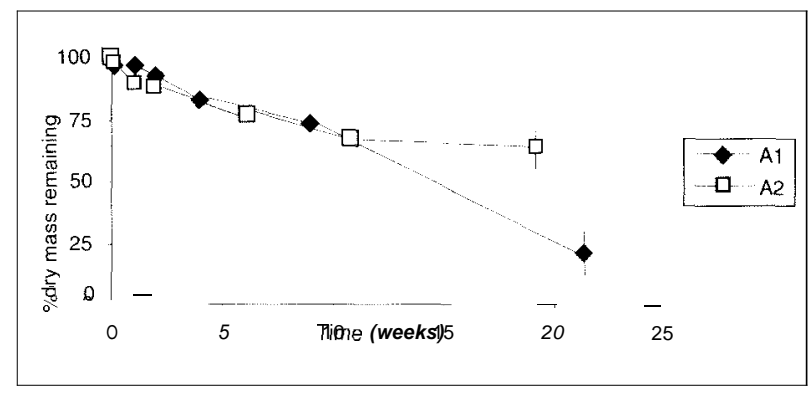

Figure 1. Mass loss of 7ypha angustifolia leaf litter during processing in Degehe. Vertical bars represent \pm SE of three replicate leaf hags. (A1: leaf hags retrieved in Spring-Sumrner; A2: leaf hags retrieved in Summer-Autumn).

Table 2. Suminary of regression analyses on mass loss data $(n=18)$. ( $n i$ $=$ dry mass $(\%), m_{0}=$ estimate of initial dry inass $(\%), k=$ decay coefficient, $t=$ incuhation time, ASE $=$ asymptotic standard error).

\begin{tabular}{cccc}
\hline & $k \pm$ ASE & $m_{b}$ & $r^{2}$ \\
spring-summer (A1) & $0.0098 \pm 0.0004$ & 108 & 0.96 \\
summer-autumn (A2) & $0.0031 \pm 0.0001$ & 92 & 0.91 \\
\hline
\end{tabular}

Tahle 1. Characteristics of the Degehe at the study site in Spring-Summer (A1) and Summer-Autumn (A2) 1996.

\begin{tabular}{|c|c|c|c|c|}
\hline \multirow[b]{2}{*}{ Parameter } & \multicolumn{2}{|c|}{ Spring-Summer } & \multicolumn{2}{|c|}{ Summer-Autumn } \\
\hline & Mean & Range & Mean & Range \\
\hline Current veiocity $\left(\mathrm{m} \mathrm{s}^{-1}\right)$ & 0.037 & $0.000-0.099$ & 0.000 & $0.000-0.000$ \\
\hline Temperature ("C) & 16.7 & 14.0-19.8 & 18.4 & $19.2-22.8$ \\
\hline $\mathrm{pH}$ & 7.5 & $7.3-7.7$ & 7.5 & $7.3-7.7$ \\
\hline Conductivity $\left(\mu \mathrm{S} \mathrm{cm}^{-1}\right)$ & 511 & $318-959$ & 725 & $582-959$ \\
\hline $\mathrm{N}-\mathrm{NO} 3\left(\mathrm{mg} \mathrm{l}^{-1}\right)$ & 0.54 & $0.26-1.03$ & 0.66 & $0.28-1.71$ \\
\hline $\mathrm{N}-\mathrm{NH} 4\left(\mathrm{mg} \mathrm{I}^{-1}\right)$ & 0.16 & $0.05-0.28$ & 0.09 & $0.06-0.17$ \\
\hline Total dissolved phosphorus $\left(\mathrm{mg}^{-1}\right)$ & 0.09 & $0.04-0.18$ & 0.16 & $0.05-0.49$ \\
\hline Dicsolved oxygen $\left(\mathrm{mg} \mathrm{l}^{-1}\right)$ & 6.0 & $1.4-8.2$ & 2.0 & $1.4-2.4$ \\
\hline Dissolved oxygen (\%) & 62.2 & $14.0-86.0$ & 23.7 & $14.0-30.0$ \\
\hline
\end{tabular}




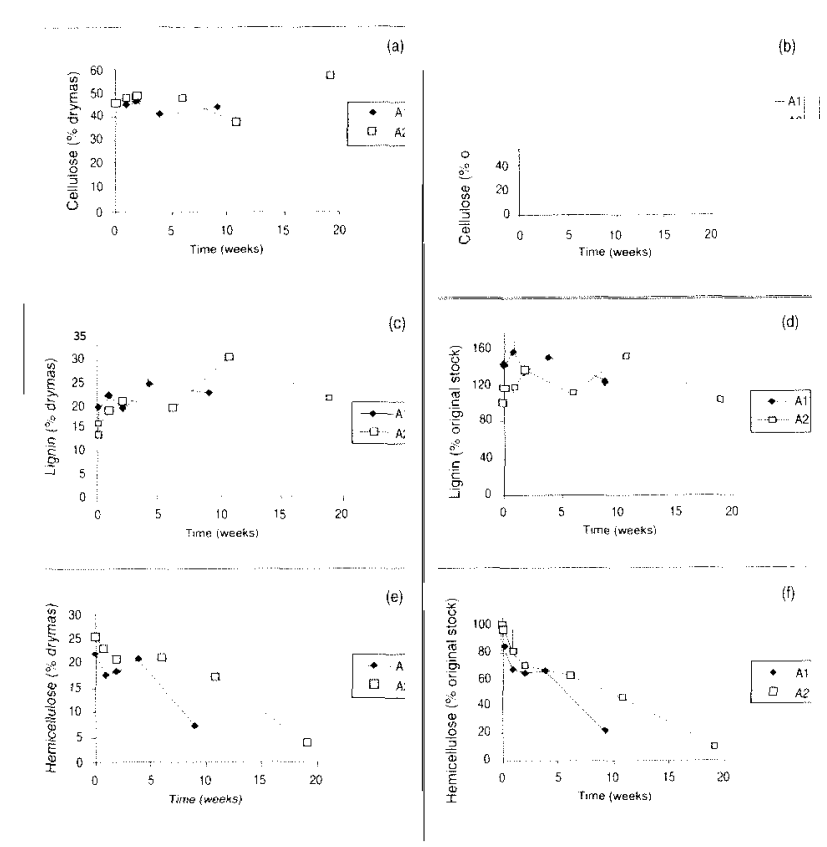

Figure 2. Changes in concentrationa (as percentage of leal dry masa) and stocks (as percentage of initial amounts per leaf bag) of cellulose $(\mathrm{a}, \mathrm{b})$, lignin (c, d) and hemicellulose $(\mathrm{e}, \mathrm{f})$ for Typha angustifolia leaves during processing in Degebe. Vertical bars represent \pm SE of three replicate leaf bags (A1: leaf bags retrieved in Spring-Summer; A2: leaf bags retrieved in Summer-Autumn)

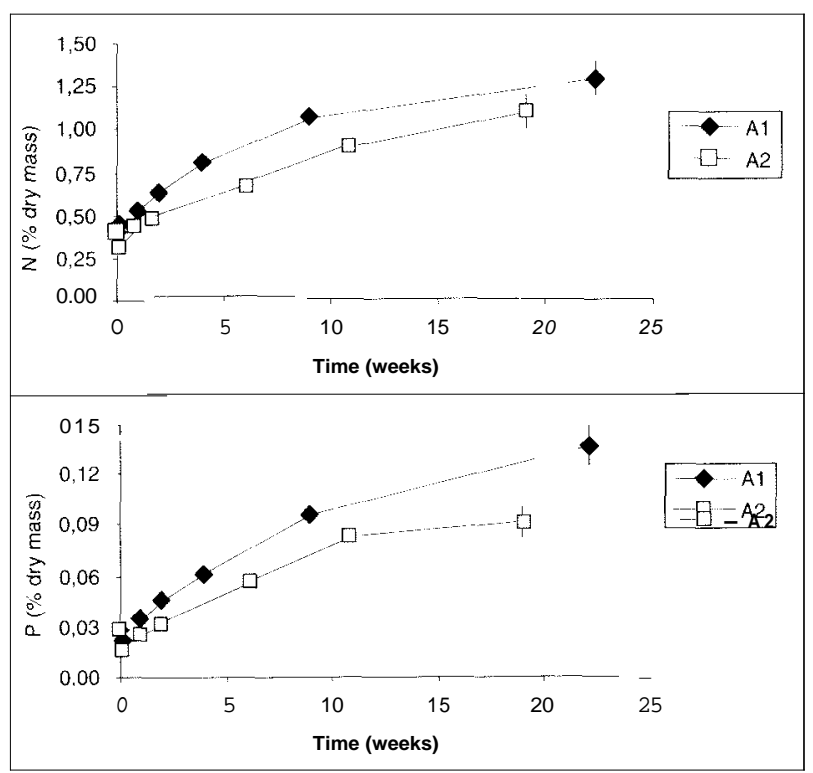

Figure 3. Changes in concentrations of phosphorus and nitrogen as a percentage of leaf dry mass for Typha angustifolia leaves during processing in Degebe. Vertical bars represent $\pm \mathbf{S E}$ of three replicate leaf bags (A1: leaf bags retrieved in Spring-Summer; A2: leaf bags retrieved in Summer-Autumn) both periods, the phosphorus declined, and then was followed by an increace. This may be related to the leaching of a small amount of this compound.

Oligochaeta, Chironomidae and Simuliidae were the moct abundant taxa in the spring experiment, while in summer the macroinvertebrates were dominated by Baetidae and Chironomidae. An increase of Gastropoda (Ancylus fluviatilis and Physa acuta) wac also observed in cummer. The almost total absence of shredders in the communities is evident, suggesting a low influence of these macroinvertebrates on the leaf decomposition.

\section{DISCUSSION}

In general, the $\mathrm{k}$ values suggest medium and low decomposition rates for Typha angustifolia (PETERSEN \& CUMMINS, 1974), although decomposition rate may have been previously over-estimated as a result of the cutting of the leaves used in the experiment (BARLOCHER \& BIDDISCONBE, 1996).

The decomposition of Typha angustifolia is faster in spring than in summer, which probably is not related to the intensity of the mechanical effect of the water flow (D'ANGELO \& WEBSTER, 1992), as the current was slow even during the first period. On the other hand, low valuec of dissolved oxygen in summer may inhibit the development of the microbial community (ANDERSON \& SEDELL, 1979; WEBSTER \& BENFIELD, 1986; BUNN, 1988) despite the higher temperature observed (e.g., BARLOCHER \& SCHWEIZER, 1983; RODGERS et al., 1983; SHORT et al., 1984). This fact is confirmed by the lower nitrogen and phosphorus contents of the leaves during the summer experiment, reflecting a lower microbial activity (CHAUVET, 1988).

The early increase of lignin contents probably reflects the formation of artefact lignin (SUBERKROPP et al., 1976). This can result from the synthesis of enzymatic complexes involved in decomposition, which may combine with plant phenols to create artefact lignin (SUBERKROPP et al., 1976; GESSNER, 1991). The formation of artefact lignin was observed after 24 hourc of processing, a result completely different from other experiments with fresh materials such as alder leaves, where the artefact lignin occurs only after two weeks of incubation (GESSNER, 1991). Microbial activity increased very rapidly after the leaves entered the water. A possible explanation could be the existence of a microbial community before the experiments as a result of the terrestrial conditioning of Typha leaves (BARLOCHER \& BIDDISCONBE, 1996), being stimulated by the wet conditions when the leaf packs were immersed in the water. 
Cellulose and hemicellulose declined more or less continuously in relation to their original mass. However, a certain variation of the decay velocity was detected. Cellulose remained practically constant until the third sample (second week), beginning a slow decay afterwards. Hemicellulose showed a rapid decline in the first three samples, stabilising in the medium samples and finishing with another accelerated loss after five weeks in the river. This third phase, not usually observed, may indicate differences in the aquatic decomposition of Typha angustifolia. The decay patterns of cellulose and lignin are similar to those observed for fresh alder leaves (GESSNER, 1991), although slower. This suggests that the aquatic decomposition of Typha angustifolia occurs in two phases. The first takes place during the two first weeks, when Typha leaves, due to their structure, remain on the water surface. Later, the leaves become completely wet and sink down to the river bed.

Our results suggest that the decomposition dynamics of Typha angustifolia include a terrestrial phase (BARLOCHER \& BIDDISCONBE, 1996) and two aquatic ones. The long residence time for dead plants in the river bed and the low decay rates permit a slow export of organic matter to the aquatic environment. This prevents high oxygen consumption in decomposition. The reduced number of shredders observed during the experiments, as well as in the Degebe throughout the year (PINTO, 1988, 1993; MORAIS, 1995), indicate that Typha angustifolia decomposition is mainly microbiological. The presence of macroinvertebrates may result from other factors not directly involved in the decomposition (SCHADE \& FISHER, 1997).

\section{ACKNOWLEDGEMENTS}

We thank Dr. Rui Cortes from the University of Trás-os Montes e Alto Douro for facilities for the determination of the leaf compounds, and two anonymous referees for comments and suggestions to the manuscript.

\section{REFERENCES}

ANDERSON, R.D. \& J.R. SEDELL, 1979. Detritus processing by macroinvertebrates in a stream ecosystem. Ann. Rev. Entomol., 24: 351-377.

APHA, 1992. Standard methods for the examination of water and waste waters. $18^{\text {th }}$ ed. American Public Health Association, Washington DC.

BARLOCHER, F. \& M. SCHWEIZER, 1983. Effects of leaf size and decay rate on colonisation by aquatic hyphomycetes. Oikos , 41: 205-210.
BARLOCHER, F. \& N.R. BIDDISCOMBE, 1996. Geratology and decomposition of Typha latifolia and Lythrum salicaria in a freshwater marsh. Arch. Hydrobiol., 136: 309 325.

BUNN, S.E., 1988. Processing of leaf litter in a northern jarrah forest stream, Westem Australia: I. Seasonal differences. Hydrobiologia, 162: 201-210.

CHAUVET, E., 1987. Changes in the composition of alder, poplar and willow leaves during decomposition in a river. Hydrobiologia, 148: 35-44.

CHAUVET, E., 1988. Influence of the environment on willow leaf litter decomposition in an alluvial corridor of the Garonne. Arch. Hydrobiol., 1 12: 371-386.

D'ANGELO, D.J. \& J.R. WEBSTER, 1992. Natural and constrainment-induced factors influencing the breakdown of dogwood and oak leaves. Hydrobiologia, 237: 39-46.

GESSNER, M.O., 1991. Differences in processing dynamics of fresh and dried leaf litter in a stream ecosystem. Freshwat. Biol., 26: 387-398.

GRAÇA, M.A.S., 1993. Patterns and processes in detritusbased systems. Limnologica, 32: 104-114.

GOERING, H.K. \& P.J. VANSOEST, 1970. Forage fibre analysis (apparatus, reagents, procedures and applications). US Dep. Agriculture Hand Book, 379: 1-20.

MASON, C.F. \& R.J. BRYANT, 1975. Production, nutrient content and decomposition of Phragmites communis Trin. and Typha angustifolia L. J. Ecol., 63: 71-95.

MORAIS, M.M., 1995. Organizaçâo espaciotemporal de um rio temporário mediterranico (rioDegebe, bacia hiodrográfica do Guadiana). Descritores fisico-químicos e produtores primários. Comunidades bentónicas de macroinvertebrados. $\mathrm{Ph} \mathrm{D}$. Thesis. University of Évora, Évora.

NEWMAN, R.M. \& J.A. PERRY, 1989. The combined effects of chlorine and ammonia on litter breakdown in outdoor experimental streams. Hydrobiologia, 184: 69-78.

PETERSEN, R.C. \& K.W. Cummins, 1974. Leaf processing in a woodland stream. Freshwat. Biol., 4: 343-368.

PINTO, P., 1988. Variação anual da estrutura cenótica da ribeira do Degebe (bacia hidrográfica do Guadiana). Actas Colóquio Luso-Espanhol sobre Bacias Hidrográficas $e$ Recursos Zoológicos, 319-326.

PINTO, P. 1993. Cinética de colonização das comunidades de macroinvertebrados aquáticos de um rio temporário do Sul de Portugal (rio Degebe, bacia hidrográfica do Guadiana). $\mathrm{Ph}$ D. Thesis. University of Évora, Évora.

RODGERS, J.H., M.E. MCKEVITT, D.O. HAMMERLUND, K.L. DICKSON \& J. CAIRNS, 1983. Primary production and decomposition of submergent and emergent aquatic 
plants of two Appalachian rivers. In: Dynamic of Jotic ecosystems. (T.D. Fontaine \& S.M. Bartell, eds.): 283-301. Ann Arbor Science. Ann Arbor.

SCHADE, J.D. \& S.G. FISHER. 1997. Lcaf litter in a Sonoran desert stream ecosystem. J. N. Am. Benthol. Soc.. 16: 612-626.

SHORT. R.A., S.L. SMITH. D.W. GUTHRIE \& J.A. STANDFORD, 1984. Leaf litter processing rates in four Texas streams. J. Freshwat. Ecol. 2: 469-473.
SUBERKROPP, K.. G.L. GODSHALK \& J.M. KLUG, 1976. Changes in chemical compositioii of leaves during processing in a woodland strcani. Ecology, 57:720-727.

WEBSTER, J.R. \& E.F. BENFIELD, 1986. Vascular plant breahdown in freshwater ecosystems. Ann. Rev. Ecol. Syst., 17: 567-594.

WIEDER, E.A. \& G.E. LANG, 1982. A critique of the analytical mcthods used in examinirig decomposition data obtained from litter bags. Ecology, 63: 1636-1642. 